論 文

\title{
サプライチェインの効率性の測定と最適化のための モデル*
}

森田＼cjkstart浩 ${ }^{\dagger} \cdot \mathrm{Joe} \mathrm{ZHU}{ }^{\ddagger}$

\author{
Models for Characterizing and Measuring Supply Chain \\ Efficiency and Achieving Best Practice*
}

Hiroshi MorITA ${ }^{\dagger}$ and Joe ZHU ${ }^{\ddagger}$

\begin{abstract}
An appropriate performance measurement system is the key to effective supply chain management. Two hurdles are present in measuring the performance of supply chain as a whole. One is the existence of multiple measures that characterize the performance of individual supply chain members. The other is the existence of conflicts between supply chain members with respect to specific measures. As a result, the efficiency of a supply chain cannot be characterized directly by the performance of supply chain members. The current study develops an approach for characterizing and measuring supply chain efficiency and achieving best practice. Models are provided to define the supply chain efficiency and to measure the performance of a supply chain as well as supply chain members. It is shown that a supply chain as a whole has potential to achieve more cost savings and a better performance through coordination and information sharing based upon our linear programming problems.
\end{abstract}

\section{1. はじめに}

サプライチエインマネジメントは高品質の製品やサー ビスを低コストで迅速により高い信頼性で提供できる手 法として非常に有用である。サプライチエイン全体にあ る資源を効率的に利用することで，市場競争力のある低 価格の製品やサービスを提供することができるからであ る。これを実現するためにはサプライチエイン全体のパ フォーマンスを評価することが必要であり, 競争に打ち 勝つための重要な情報となる。しかし, 従来から企業内 に大きなサプライチエインシステムを持っている企業で も，流通ネットワーク全体にわたるパフォーマンスを評 価するシステムは持っていないことが多い $[6,9]$.

サプライチエインマネジメントの考え方は, サプライ チエインを構成する個々のメンバーよりもサプライチエ イン全体のパフォーマンスを重視している. 個々のメン

\footnotetext{
* 原稿受付 2002 年 8 月 19 日

$\dagger$ 大阪大学 大学院 情報科学研究科 Graduate School of Information Science and Technology, Osaka University; Yamadaoka, Suita, Osaka 565-0871, JAPAN

‡ ウースター工芸大学 経営学部 Department of Management, Worcestor Polytechnich Institute; Worcester, MA 01609, U.S.A.

Key Words: supply chain, efficiency, best practice, performance, data envelopment analysis.
}

バーが完全に効率的な方策をもっていたとしても，メン バー間での入出力の相互関係によって非効率的になって しまうこともある。サプライチエインのパフォーマンス を評価するには，メンバーに関係する複数のパフォーマ ンスの評価項目を取り扱い, 個々のパフォーマンスを統 合させる必要がある。

一般にトレードオフにある入出力において最も効率的 な関係を定量的に記述することは難しいため，いくつか の同種の活動をしているサプライチエインで実際に得ら れた観測值を相対的に比較することで，その入出力関係 を表すトレードオフ曲線を求め, それとの差異によって 最良のパフォーマンスを実現しているかどうかを評価す ることを考える。このような相対的効率性を評価する方 法にデー夕包絡分析法 (DEA) [2,12]がある. DEA では 「入力」に対する「出力」の比によって効率性を表し, 与 えられたデータから推定された入出力に対するトレード オフ曲線（効率的フロンティアという）を基準にして効 率性を評価している。

サプライチエインにおける個々のメンバーの効率性 はこの入出力比によって定義することができるが，この DEA の評価手法をサプライチエイン全体の効率性の評 価にそのまま適用することはできない.なぜならいくつ かの入出力項目は個々のメンバー間で互いに関連してい 


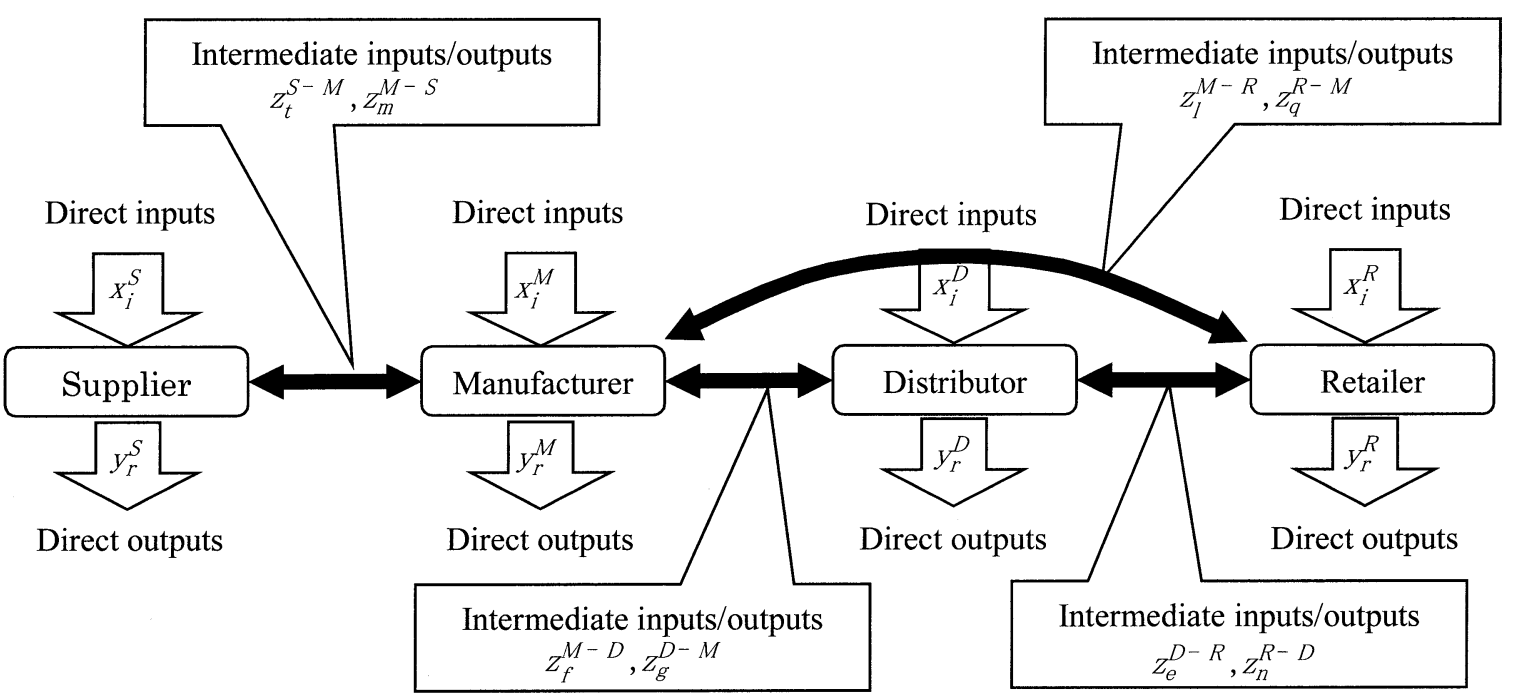

Fig. 1 Supply chain as an input-output system

るために競合関係が存在し, 単純にサプライチエインの 「出力」とか「入力」に分類できないからである．単に サプライチエインの総コストを最小にしたり総利益を最 大にしたりするのではこの競合関係をモデル化すること にはならない。サプライチエインの効率性を測定するに はサプライチエインとその構成メンバーに対して効率性 を測定できるモデルが必要となる。

単一のパフォーマンス尺度を使ってサプライチエイン のパフォーマンスを推定する方法 [3] もあるが, サプラ イチエインを最適化するための方策は考えられていな い.このほかにサプライチエインのパフォーマンスを経 営面から考察したもの [5]もある.しかし, 評価項目の 間に存在する競合を考慮したサプライチエイン全体のパ フォーマンスが考えられておらず，また個々のメンバー のパフォーマンスの評価がなく, 最適化とそのための改 善目標が示されていないなどの問題点が挙げられる.

本論文ではサプライチエイン全体のパフォーマンスの 効率性と個々のメンバーのパフォーマンスの効率性をそ れぞれ測定し，これらの関係を明らかにするとともに， 個々のメンバーの評価項目の取るべき最適な值を示す手 法を提案する。サプライチエイン全体が最適になるため には個々のメンバーが効率的な活動をすることが必要で ある．提案するモデルではメンバーが協力し情報を共有 することでさらにコスト削減が達成され, 全体としてよ りよいパフォーマンスを実現できることが示される.

提案手法では複数存在するパフォーマンスの評価項目 に関するいかなる仮定も用いず, 効率的なサプライチエ インを構成するときの評価項目の最適な值を得ることが できる．実際のサプライチエインにおける観測值から相 対的な比較により構成される効率的フロンティアを区分 的に線形近似して求めており, 典型的な数学モデルや確 率モデルで仮定している非現実的な仮定を必要としてい ない.
本論文では，まず 2. でサプライチエインのパフォーマ ンスと入出力システムとしてのサプライチエインについ て述べる，そこでは個々のメンバーとともにサプライチ エインの効率性を明らかにし, その測定のためのモデル を示す. 3. ではサプライチエインの効率性と個々のメン バーの効率性の関係を明らかにする.4. で数值例を示し, 最後に5. では今後の方向とともに結論を述べている.

\section{2. 入出カシステムとしてのサプライチエ イン}

サプライヤ, 生産者, 流通業者, 小売業者の四つメン バーから構成されているサプライチエインの例を Fig. 1 に示す.サプライチエインマネジメントの一般的な目的 はメンバー間の適切な調整によってサプライチエイン全 体のコストを最小化することであり $[1,4]$, そのためには サプライチエイン全体と個々のメンバーのパフォーマン スをそれぞれ適切に評価する必要がある。 パフォーマン スの評価システムとして望まれることは, パフォーマン スを表すために必要な情報を提供し, 最適なサプライチ エインを同定することによってサプライチエインを監視 かつ管理し, 更なるサプライチエインの改善の方向を示 すことである。

サプライチエインには, コスト, 柔軟性, 顧客サービ ス, 時間, 品質などいろいろな目的があり, 一つの評価 規準だけでは交互作用, 代替性, トレードオフなどを適 切に評価できない.トレードオフの例として, サプライ チエインの総コストと発注から納品までのレスポンス時 間を考えてみよう. Fig. 2 は最適なサプライチエインの パフォーマンスを表す効率的フロンティア曲線とその曲 線によって優越される領域を例示している. 効率的フロ ンティア上にある点 (たとえば $\left.S_{1}, S_{2}, S_{3}\right)$ は, 総コス トとレスポンス時間の両方において優れているものが存 在しないという意味で優越されない, すなわち効率的で 


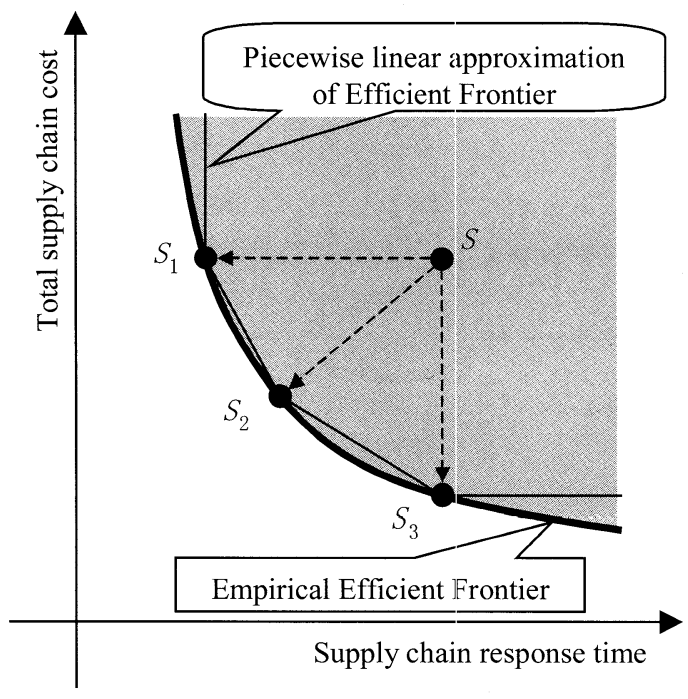

Fig. 2 Efficient frontier of supply chain performance

あるという．DEA では効率的フロンティアを区分的な 線形関数として同定する. そして, 点 $S$ のような非効率 的なパフォーマンスは点 $S_{1}, S_{2}, S_{3}$ またはフロンティ ア上の他の点へ向かう方向に沿って改善することで効率 的にさせることができる。

あらゆる管理システムや生産システムは入力を出力へ 変換するシステムと見ることができ，その効率性は入力 に対する出力の比で定義できる. サプライチエインシス テムもまた原材料や要素を付加価值のある製品やサー ビスへ変換するものと見ることができ，その効率性も入 力と出力を用いて定義することができる。 サプライチエ インは個々のメンバーが統合された入出力システムで, 各メンバーはコストや資源といった入力を利益や収入と いった出力へ変換している. メンバーのパフォーマンス の評価項目はサプライチエインシステムにおける物や情 報の流れに基づいて入力と出力に分類することができる.

各メンバー $\Delta$ に打ける入力と出力の集合をそれぞれ $I^{\Delta}$ と $R^{\Delta}$ とし, その観測值を $\left(x_{i}^{\Delta}, y_{r}^{\Delta}\right), i \in I^{\Delta}, r \in R^{\Delta}$ とする，複数のサプライチエイン恓あるとき，各メン バーの効率性は, 同種のメンバーを相対的に比較する DEA 効率性に従って定めることができる．効率的なメ ンバーが構成するのが効率的フロンティアであり，他の メンバーに優越されないメンバーである.

メンバーの効率性の定義をサプライチエインの効率性 へ適用することはできない. なぜなら，いくつかの評価 項目は複数のメンバーに関連しているために, 単純にサ プライチエインの「入力」または「出力」に分類するこ とができないからである。サプライチエインシステムの 評価項目は 2 種類に分けられる。一つは特定のメンバー だけの評価項目でこれらを直接入出力とよぶ。たとえば 労務費や製造時間は生産者の直接入力となる。各メン バーの直接入出力はサプライチエインの入出力と見るこ とができる。一方，複数のメンバーに共通する間接入出
力もある。たとえば，生産者から小売業者や配送業者へ 送られた製品数は生産者にとっては出力になるが，小売 業者や配送業者にとっては入力となる．間接入出力は特 定のメンバーにとっては入力か出力となるが, サプライ チエインでは単純に入力とか出力にはならない.サプラ イチエインマネジメントでは間接入出力の值は互いの利 害関係があるため，メンバー間の交渉によって決まるも のである $[8,11]$.

メンバー $\Delta$ の直接入力と直接出力の集合をそれぞれ $D I^{\Delta}$ と $D R^{\Delta}$ で表す. 間接出力には以下の記号を用いる.

- $z_{t}^{S-M}, t=1, \cdots, T$ : サプライヤから生産者へ

- $z_{m}^{M-S}, m=1, \cdots, M$ : 生産者からサプライヤへ

- $z_{f}^{M-D}, f=1, \cdots, F$ : 生産者加流通業者へ

- $z_{g}^{D-M}, g=1, \cdots, G$ : 流通業者加生産者へ

- $z_{l}^{M-R}, l=1, \cdots, L$ : 生産者加小売業者へ

- $z_{q}^{R-M}, q=1, \cdots, Q$ : 小売業者から生産者へ

- $z_{e}^{D-R}, e=1, \cdots, E$ : 流通業者加小売業者へ

- $z_{n}^{R-D}, n=1, \cdots, N$ : 小売業者から流通業者へ

間接入力は相対するメンバーの間接出力となるので記号 は定義していない. たとえば $z_{t}^{S-M}$ は, サプライヤに とっては出力で生産者にとっては入力となる.

\section{3. サプライチエインの効率性}

いろいろな評価項目間のトレードオフや関数形がわ かっていれば，効率的フロンティアを求めるのに最適化 手法を用いることもできるが，そのような情報を完全に 得ることは難しい。そこで，サプライチエイン自身の評 価と最適化を図るために，他の同様なサプライチエイン と相対的な比較を行う。そこでは，あるサプライチエイ ンの多期間にわたる観測值またはある時点における同様 なサプライチエインの観測值に基づいて効率的フロン ティアを経験的に推定し, 最適なサプライチエインのパ フォーマンスを評価することになる。

\section{1 サプライチエインのメンバーの効率性}

$J$ 個のサプライチエインがあり，メンバー $\Delta$ は入出 力值 $x_{i j}^{\Delta}\left(i \in I^{\Delta}\right), y_{r j}^{\Delta}\left(r \in R^{\Delta}\right), j=1, \cdots, J$ をもつもの とする. 効率的フロンティアはこれらの $J$ 組の観測值か ら構成される. $j_{0}$ 番目のサプライチエインにおけるメン バー $\Delta$ の入出力の観測值は $\left(x_{j_{o}}^{\Delta}, y_{j_{o}}^{\Delta}\right)$ と表され, その効 率性は次の線形計画問題で表されるモデル 1 によって求 められる。

$$
\begin{aligned}
& \text { 《モデル } 1 》 \\
& \theta_{\Delta}^{*}=\min _{\phi_{j}^{\Delta}, \theta_{\Delta}} \theta_{\Delta} \\
& \text { subject to } \sum_{j=1}^{J} \phi_{j}^{\Delta} x_{i j}^{\Delta} \leq \theta_{\Delta} x_{i j_{o}}^{\Delta}, \quad i \in I^{\Delta} \\
& \qquad \sum_{j=1}^{J} \phi_{j}^{\Delta} y_{r j}^{\Delta} \geq y_{r j_{o}}^{\Delta}, \quad r \in R^{\Delta}
\end{aligned}
$$


Table 1 Simple numerical example

\begin{tabular}{|c|c|c|c|c|c||c|c|c|}
\hline & \multicolumn{3}{|c|}{ Supplier } & \multicolumn{2}{c||}{ Manufacturer } & \multicolumn{3}{c|}{ Efficiency } \\
\hline Supply chain & Shipping cost & Labor & Revenue & Material costs & Profit & Supplier & Manufacturer & Overall \\
\hline A & 6 & 8 & 3.0 & 15 & 0.5 & 0.682 & 1 \\
\hline B & 8 & 3 & 6.0 & 12 & 1 & 0.545 & 0.545 \\
\hline C & 10 & 4 & 2.0 & 22 & 0.333 & 1 & 1 \\
\hline
\end{tabular}

$$
\phi_{j}^{\Delta} \geq 0, \quad j=1, \cdots, J
$$

モデル 1 は複数の評価項目をもつシステムの相対的効率 性を測定するためのDEA モデルであり，(2) 式に示す入 出力比を最大にする重みを決定するための分数計画問題 を等価変換して得られる線形計画問題の双対問題となっ ている。

$$
\begin{aligned}
& \theta_{\Delta}^{*}=\max \sum_{r=1}^{s} \mu_{r} y_{r o} / \sum_{i=1}^{m} v_{i} x_{i o} \\
& \text { subject to } \sum_{r=1}^{s} \mu_{r} y_{r j} / \sum_{i=1}^{m} v_{i} x_{i j} \leq 1, \quad j=1, \cdots, n \\
& v_{i} \geq 0, \quad i=1, \cdots, m, \quad \mu_{r} \geq 0, \quad r=1, \cdots, s
\end{aligned}
$$

ここで' $v_{i} \geq 0, \quad i=1, \cdots, m, \mu_{r} \geq 0, r=1, \cdots, s$ は入出力 にかかる重みを表す。 $\theta_{\Delta}^{*}$ は重みつき入出力比であり, 効 率性尺度として用いられる。DEA モデルでは効率的フ ロンティアとそれに囲まれる領域を区分的線形に近似し て求めている.

【定理 1】 $[2,12] \quad\left(x_{j_{o}}^{\Delta}, y_{j_{o}}^{\Delta}\right)$ が他に優越されないための 必要十分条件は, モデル 1 の最適值が $\theta^{\Delta^{*}}=1$ となるこ とである。

効率的フロンティアは $\theta_{\Delta}^{*}=1$ となる観測值から構成 される. $\theta_{\Delta}^{*}=1$ のときでも入出力にスラック

$$
\begin{aligned}
& s_{i}^{-^{*}}=x_{i j_{o}}^{\Delta}-\sum_{j=1}^{J} \phi_{j}^{\Delta^{*}} x_{i j}^{\Delta}, \quad i \in I^{\Delta} \\
& s_{r}^{+^{*}}=\sum_{j=1}^{J} \phi_{j}^{\Delta^{*}} y_{r j}^{\Delta}-y_{r j_{o}}^{\Delta}, \quad r \in R^{\Delta}
\end{aligned}
$$

が存在することがあり，(3)式に一つでも正のスラックが 存在すれば $\left(x_{j_{o}}^{\Delta}, y_{j_{o}}^{\Delta}\right)$ は弱効率的であるという. $\theta_{\Delta}^{*}=1$ な らば，メンバー $\Delta$ は効率的（弱効率的を含む）であるとい う. 非効率的なメンバーに対しては, 最適值 $\sum_{j=1}^{J} \phi_{j}^{\Delta^{*}} x_{i j}^{4}$ と $\sum_{j=1}^{J} \phi_{j}^{\Delta^{*}} y_{r j}^{\Delta}$ によって効率的フロンティア上への射影 が求められる。

各メンバーについてモデル 1 を解くと, それぞれの メンバーの効率性 $\theta_{\Delta}^{*}$ を求めることができる. 例として Table 1 に示すサプライヤと生産者からなる三つのサプ ライチエイン A， B， C を考える。 サプライヤは二つの 入力 (輸送コストと労働力) と一つの出力（生産者へ販 売した原材料からの収益）をもち，生産者は一つの入力 (サプライヤの収益である原材料コスト) と一つの出力 (利益)をもつものとする。モデル 1 を適用すると, B
のサプライヤと $\mathrm{C}$ の生産者のみが効率的となる。間接入 出力である収益（原材料コスト）を無視してモデル 1 を 適用すると, Table 1 の最右列にあるように A と C が効 率的となる。このように個々のメンバーにモデル 1 を適 用してもサプライチエインの効率性を表すことにはなら ない.

次の定理は, モデル 1 において, 一つの評価項目を同 時に入力と出力に用いることができないことを示して いる。

【定理 2】評価項目 $z_{k}$ を入力と出力に同時に用いた ら，モデル 1 の最適值はつねに 1 となる。

(証明) モデル 1 より，入力に関する制約条件から $\sum_{j=1}^{J} \phi_{j} z_{k j} \leq \theta z_{k j_{o}}$, 出力に関する制約条件から $\sum_{j=1}^{J} \phi_{j}$ $z_{k j} \geq z_{k j_{o}}$ が得られるので, $\theta \geq 1$ となる.よって $\theta^{*}=1$ となる。

\section{2 サプライチエインの効率性}

サプライチエインのパフォーマンスをモデル 1 で単純 に定義することはできない理由をまとめると以下のよう になる．第 1 に間接入出力はメンバーにとっては入力ゃ 出力になってもサプライチエインの入力または出力とし て単純に扱うことはできない。第 2 に定理 2 より，間接 入出力を一つの線形計画モデル 1 でモデル化するとメン バーのパフォーマンスとは関係なくサプライチエインが 効率的であると評価されてしまう。モデル 1 を使うとす べてのメンバーを効率的にすることはできるけれども， それではサプライチエインの効率性を測定していること にはならない $[10]$. 第 3 にモデル 1 において 0 でない $\phi_{j}^{\Delta^{*}}$ は評価対象のメンバーにとってのベンチマークを表して いるが，サプライチエイン全体での各メンバーのベンチ マークは必ずしもそれと一致しない. 第 4 にモデル 1 で サプライチエイン全体の効率性を測定するのでは, 各メ ンバーは同じ効率性を有していると仮定されており, 効 率性の違いを見ることはできない.

そこで, Fig. 1 に示した四つのメンバーからなるサプ ライチエインを例にして，効率性を測定するためのモデ ルを提案する。メンバーのパフォーマンスに対する選好 度を表すウェイトとして $w_{S}+w_{M}+w_{D}+w_{R}=1$ を満 たす正のウエイトを与えるが，メンバーに対する選好度

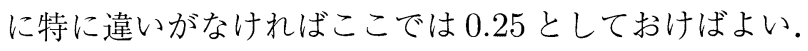
各メンバーの評価項目を統合して一つの線形計画問題を 作り, $j_{0}$ 番目のサプライチエイン全体の相対的な効率性 を測定するモデル 2 を与える。 
《モデル 2》

$\Omega^{*}=\min _{\Omega_{i}, \lambda_{i}, \beta_{i}, \delta_{i}, \gamma_{i}, \tilde{z}} w_{S} \Omega_{S}+w_{M} \Omega_{M}+w_{D} \Omega_{D}+w_{R} \Omega_{R}$

subject to

(サプライヤ)

$$
\begin{array}{ll}
\sum_{j=1}^{J} \lambda_{j} x_{i j}^{S} \leq \Omega_{S} x_{i j_{o}}^{S} & i \in D I^{S} \\
\sum_{j=1}^{J} \lambda_{j} y_{r j}^{S} \geq y_{r j_{o}}^{S} & r \in D R^{S} \\
\sum_{j=1}^{J} \lambda_{j} z_{t j}^{S-M} \geq \tilde{z}_{t j_{o}}^{S-M} & t=1, \cdots, T \\
\sum_{j=1}^{J} \lambda_{j} z_{m j}^{M-S} \leq \tilde{z}_{m j_{o}}^{M-S} & m=1, \cdots, M \\
\lambda_{j} \geq 0 & j=1, \cdots, J
\end{array}
$$

(生産者)

$$
\begin{aligned}
& \sum_{j=1}^{J} \beta_{j} x_{i j}^{M} \leq \Omega_{M} x_{i j_{o}}^{M} \quad i \in D I^{M} \\
& \sum_{j=1}^{J} \beta_{j} y_{r j}^{M} \geq y_{r j_{o}}^{M} \quad r \in D R^{M} \\
& \sum_{j=1}^{J} \beta_{j} z_{t j}^{S-M} \leq \tilde{z}_{t j_{o}}^{S-M} \quad t=1, \cdots, T \\
& \sum_{j=1}^{J} \beta_{j} z_{m j}^{M-S} \geq \tilde{z}_{m j_{o}}^{M-S} \quad m=1, \cdots, M \\
& \sum_{j=1}^{J} \beta_{j} z_{f j}^{M-D} \geq \tilde{z}_{f j_{o}}^{M-D} \quad f=1, \cdots, F \\
& \sum_{j=1}^{J} \beta_{j} z_{g j}^{D-M} \leq \tilde{z}_{g j_{o}}^{D-M} \quad g=1, \cdots, G \\
& \sum_{j=1}^{J} \beta_{j} z_{l j}^{M-R} \geq \tilde{z}_{l j_{o}}^{M-R} \quad l=1, \cdots, L \\
& \begin{array}{ll}
\sum_{j=1}^{J} \beta_{j} z_{q j}^{R-M} \leq \tilde{z}_{q j_{o}}^{R-M} & q=1, \cdots, Q \\
\beta_{j} \geq 0 & j=1, \cdots, J
\end{array}
\end{aligned}
$$

(流通業者)

$$
\begin{array}{ll}
\sum_{j=1}^{J} \delta_{j} x_{i j}^{D} \leq \Omega_{D} x_{i j_{o}}^{D} & i \in D I^{D} \\
\sum_{j=1}^{J} \delta_{j} y_{r j}^{D} \geq y_{r j_{o}}^{D} & r \in D R^{D} \\
\sum_{j=1}^{J} \delta_{j} z_{f j}^{M-D} \leq \tilde{z}_{f j_{o}}^{M-D} & f=1, \cdots, F \\
\sum_{j=1}^{J} \delta_{j} z_{g j}^{D-M} \geq \tilde{z}_{g j_{o}}^{D-M} & g=1, \cdots, G
\end{array}
$$

$$
\begin{array}{ll}
\sum_{j=1}^{J} \delta_{j} z_{e j}^{D-R} \geq \tilde{z}_{e j_{o}}^{D-R} & e=1, \cdots, E \\
\sum_{j=1}^{J} \delta_{j} z_{n j}^{R-D} \leq \tilde{z}_{n j_{o}}^{R-D} & n=1, \cdots, N \\
\delta_{j} \geq 0 & j=1, \cdots, J
\end{array}
$$

(小売業者)

$$
\begin{array}{ll}
\sum_{j=1}^{J} \gamma_{j} x_{i j}^{R} \leq \Omega_{R} x_{i j_{o}}^{R} & i \in D I^{R} \\
\sum_{j=1}^{J} \gamma_{j} y_{r j}^{R} \geq y_{r j_{o}}^{R} & r \in D R^{R} \\
\sum_{j=1}^{J} \gamma_{j} z_{l j}^{M-R} \leq \tilde{z}_{l j_{o}}^{M-R} & l=1, \cdots, L \\
\sum_{j=1}^{J} \gamma_{j} z_{q j}^{R-M} \geq \tilde{z}_{q j_{o}}^{R-M} & q=1, \cdots, Q \\
\sum_{j=1}^{J} \gamma_{j} z_{e j}^{D-R} \leq \tilde{z}_{e j_{o}}^{D-R} & e=1, \cdots, E \\
\sum_{j=1}^{J} \gamma_{j} z_{n j}^{R-D} \geq \tilde{z}_{n j_{o}}^{R-D} & n=1, \cdots, N \\
\gamma_{j} \geq 0 & j=1, \cdots, J
\end{array}
$$

モデル 2 には他のいろいろな条件を付け加えることもで きる，たとえば，生産者から流通業者へ運ばれる製品数 $z_{f}^{M-D}$ に対して, 生産者の生産容量が $C_{f}$ であれば, 制 約条件 $\tilde{z}_{f}^{M-D} \leq C_{f}$ を付け加えればよい.

【定理 3】 $\Omega^{*}=1$ ならば，モデル 2 には最適解 $\lambda_{j_{o}}^{*}=$ $\beta_{j_{o}}^{*}=\delta_{j_{o}}^{*}=\gamma_{j_{o}}^{*}=1$ が存在する.

（証明） $\Omega^{*}=1$ であることと $\Omega_{S}^{*}=\Omega_{M}^{*}=\Omega_{D}^{*}=\Omega_{R}^{*}=1$ であることは同值である。また次の解はモデル 2 の実行 可能解となる.

$$
\begin{aligned}
& \lambda_{j_{o}}^{*}=\beta_{j_{o}}^{*}=\delta_{j_{o}}^{*}=\gamma_{j_{o}}^{*}=1, \\
& \Omega_{S}^{*}=\Omega_{M}^{*}=\Omega_{D}^{*}=\Omega_{R}^{*}=1, \\
& \tilde{z}_{t j_{o}}^{S-M^{*}}=z_{t j_{o}}^{S-M}, \tilde{z}_{m j_{o}}^{M-S^{*}}=z_{m j_{o}}^{M-S}, \tilde{z}_{f j_{o}}^{M-D^{*}}=z_{f j_{o}}^{M-D}, \\
& \tilde{z}_{l j_{o}}^{M-R^{*}}=z_{l j_{o}}^{M-R}, \tilde{z}_{q j_{o}}^{R-M^{*}}=z_{q j_{o}}^{R-M}, \tilde{z}_{e j_{o}}^{D-R^{*}}=z_{e j_{o}}^{D-R}
\end{aligned}
$$

したがって，モデル 2 には $\lambda_{j_{o}}^{*}=\beta_{j_{o}}^{*}=\delta_{j_{o}}^{*}=\gamma_{j_{o}}^{*}=1$ とな る最適解が存在する。

【定理 4】 $\theta_{\Delta}^{*}$ をモデル 1 の最適值とするとき, $\Omega^{*}=1$ ならば $\theta_{\Delta}^{*}=1$ である.

(証明) $\Omega^{*}=1$ とすると, 定理 3 より, 最適解は $\lambda_{j_{o}}^{*}=$ $\beta_{j_{o}}^{*}=\delta_{j_{o}}^{*}=\gamma_{j_{o}}^{*}=1$ となる.ここでモデル 1 においてい くつかが $\theta_{\Delta}^{*}<1$ ，たとえば $\theta_{S}^{*}<1$ であると仮定すると， $\Omega_{1}^{*}=1$ はモデル 2 において最適解ではない. よってすべ て $\theta_{\Delta}^{*}=1$ である。

定理 1 と定理 4 より， $\Omega^{*}=1$ のとき，すべてのメンバー は効率的となることがわかる.また，(6) 式の值を入出 力にもつサプライチエインであれば， $\Omega^{*}=1$ となるた 
め，定理 4 よりそのサプライチエインを構成するすべて のメンバーは効率的となることがわかる.

$$
\begin{aligned}
& \Omega_{\Delta}^{*} x_{i j_{o}}^{\Delta}\left(i \in D I^{\Delta}\right), \quad y_{r j_{o}}^{\Delta}\left(r \in D R^{\Delta}\right), \\
& \tilde{z}_{t j_{o}}^{S-M^{*}}(t=1, \cdots, T), \quad \tilde{z}_{m j_{o}}^{M-S^{*}}(m=1, \cdots, M), \\
& \tilde{z}_{f j_{o}}^{M-D^{*}}(f=1, \cdots, F), \quad \tilde{z}_{g j_{o}}^{D-M^{*}}(g=1, \cdots, G), \\
& \tilde{z}_{l j_{o}}^{M-R^{*}}(l=1, \cdots, L), \quad \tilde{z}_{q j_{o}}^{R-M^{*}}(q=1, \cdots, Q), \\
& \tilde{z}_{e j_{o}}^{D-R^{*}}(e=1, \cdots, E), \quad \tilde{z}_{n j_{o}}^{R-D^{*}}(n=1, \cdots, N)
\end{aligned}
$$

【定義 1】モデル 2 の最適值が $\Omega^{*}=1$ のとき，サプ ライチエインは効率的であるという.

モデル 2 ではすべての間接入出力は決定変数となって いる. 各メンバー $\Delta$ がモデル 2 から決められる間接入 出力の最適值をとるとき, ほかに優越されないパフォー マンスとなりサプライチエインが効率的となる．間接入 出力の最適值は線形計画問題による最適化を通じてメン バー間での調整がなされているが，サプライチエインヘ の入力である直接入力は $\Omega_{\Delta}$ によって最適な值が与えら れる、モデル 2 はサプライチエインのパフォーマンスの 効率值 $\Omega^{*}$ をえるだけでなく, すべてのメンバーが効 率的となるための間接入出力の最適值も与える. サプラ イチエインのパフォーマンスの効率的フロンティアはメ ンバーの効率的フロンティアの集合によって決まる。さ らに系 1 によると，モデル 2 はサプライチエインが最良 のパフォーマンスを達成するための方向も示す.

$\theta_{\Delta}^{*}$ はメンバーが最良のパフォーマンスを実現してい るという仮定のもとでのメンバー $\Delta$ の効率性を測定する ものである.また， $\Omega_{\Delta}^{*}$ はサプライチエインが最良のパ フォーマンスを実現しているときのメンバー $\Delta$ の効率性 尺度として用いることができる。

【定義 2】 サプライチエインが最良のパフォーマンス を実現しているとき, 各メンバー $\Delta$ の効率值を $\Omega_{\Delta}^{*}$ と する。

$\Omega^{*}$ は非効率的なサプライチエインに対するコスト 削減効果を表していると見ることもできる． $\Omega^{*}$ が小 さければ小さいほど，最良のパフォーマンスを実現す ることでより大きな削減効果が得られる. 同様のこと は，メンバーが最良のパフォーマンスを実現している という仮定のもとで， $\theta_{\Delta}^{*}$ についてもいえる。ここで $w_{S} \theta_{S}^{*}+w_{M} \theta_{M}^{*}+w_{D} \theta_{D}^{*}+w_{R} \theta_{R}^{*}$ はすべてのメンバーを 結合させることによって得られた入力削減を示す指数を 表している。次の定理は, サプライチエイン全体では, よりよいパフォーマンスを期待できることを示している.

【定理 5】 $\Omega^{*} \leq w_{S} \theta_{S}^{*}+w_{M} \theta_{M}^{*}+w_{D} \theta_{D}^{*}+w_{R} \theta_{R}^{*}$

(証明) $\theta_{\Delta}^{*}$ はモデル 2 の実行可能解であることから明 らかである。

\section{4. 数值例}

提案したモデルにつぎの数値データを適用して，解析 例を示す。

\section{1 データとモデル}

サプライヤでは，二つの直接入力として労働力と操業 コストを，一つの間接出力として収益をとる。この収益 は生産者にとっての間接入力となる.

生産者では，サプライヤの収益である間接入力のほか に二つの直接入力として製造コストと生産リードタイム をとる。三つの間接出力として流通業者へ送られた製品 数, 小売業者へ送られた製品数, 流通業者の在庫率をと る。これらは流通業者や小売業者にとっての間接入力と なる，流通業者の在庫率は在庫維持費用などに関わって いるため，流通業者にとってのコストになるが，在庫率 を高くするには生産者から多くの製品が送られてこなけ ればならないので, 生産者にとっては収益を意味するこ とになる。したがって，在庫率は流通業者にとっては入 力，生産者にとっては出力となる.

流通業者では，生産者からの間接入力のほかに二つの 直接入力として在庫コストと流通コストをとり，二つの 間接出力として小売業者へ送られる製品数と納期内配送 率をとる。

小売業者では，生産者と流通業者からの間接入力のほ かに一つの直接入力として注文残数をとり，一つの直接 出力として利益をとる.

$J=10$ 種類のサプライチエインが存在しているものと して，それらの観測值を Table 2 に示す。この中から最 良のパフォーマンスをもつ効率的なサプライチエインを 求め, 非効率的なサプライチエインに対しては改善の目 標となるベンチマークを与える.

\section{2 サプライチエインの効率性}

Table 3 はモデル 1 と $w_{S}=w_{M}=w_{D}=w_{R}=0.25$ と したモデル 2 に対する効率值を示している．ここでは在 庫率と納期内配送率は 100 [\%] 以下であるという制約条 件を付け加えている．第 2 列から第 5 列にはモデル 1 に よる各メンバーの効率性を示し，第 6 列にその平均を示 している．モデル 2 によるサプライチエインの効率性は 第 7 列以降に示している. 第 8 列から第 11 列に各メン バーの効率性を示し，第 7 列にはサプライチエイン全体 の効率性を示している.

個々のメンバーは多くのサプライチエインで効率的と なっているが，SC 7 が全体として効率的となっており， 最良のパフォーマンスをしている．効率值は最良のパ フォーマンスを達成するために必要な入力削減量でもあ る. 第 6 列にあるメンバーの効率值の平均值は第 7 列の サプライチエインの効率值 $\Omega^{*}$ より大きい. たとえば SC 5 では二つのメンバー（生産者と流通業者）が効率的で, メンバーの効率值の平均は 0.929 , サプライチエイン全 体の効率值は 0.795 である。これはサプライチエインシ 
Table 2 Data

\begin{tabular}{|l|c|c|c|c|c|c|c|c|c|c|}
\hline \multicolumn{1}{|c|}{ SC } & 1 & 2 & 3 & 4 & 5 & 6 & 7 & 8 & 9 & 10 \\
\hline Labor & 150 & 140 & 130 & 165 & 170 & 145 & 155 & 175 & 160 & 125 \\
\hline Operating cost & 130 & 150 & 165 & 170 & 200 & 185 & 135 & 190 & 185 & 190 \\
\hline Revenure & 20 & 21 & 23 & 24 & 27 & 25 & 24 & 30 & 28 & 25 \\
\hline Manufacturing cost & 125 & 120 & 110 & 150 & 146 & 115 & 105 & 100 & 135 & 120 \\
\hline Manufacturing lead time & 3 & 2 & 3 & 4 & 2 & 3 & 2 & 2 & 4 & 3 \\
\hline Fill rate & $70[\%]$ & $90[\%]$ & $78[\%]$ & $88[\%]$ & $73[\%]$ & $95[\%]$ & $89[\%]$ & $87[\%]$ & $95[\%]$ & $90[\%]$ \\
\hline Distributor inventory cost & 90 & 100 & 80 & 70 & 85 & 77 & 78 & 90 & 78 & 68 \\
\hline Distribution cost & 300 & 300 & 200 & 400 & 200 & 200 & 100 & 300 & 200 & 100 \\
\hline On-time delivery & $96[\%]$ & $95[\%]$ & $97[\%]$ & $89[\%]$ & $99[\%]$ & $89[\%]$ & $93[\%]$ & $88[\%]$ & $99[\%]$ & $83[\%]$ \\
\hline Average number of backorder & 10 & 11 & 13 & 12.5 & 14 & 13.5 & 12.5 & 15.5 & 13.5 & 13 \\
\hline Retailer profit & 31000 & 22000 & 30000 & 23000 & 32000 & 24000 & 35000 & 37000 & 32500 & 35500 \\
\hline $\begin{array}{l}\text { Products shipped } \\
\text { from distributor to retailer }\end{array}$ & 1800.0 & 2000.0 & 2400.0 & 2300.0 & 2500.0 & 2500.0 & 2000.0 & 2000.0 & 2500.0 & 2300.0 \\
\hline $\begin{array}{l}\text { Products shipped } \\
\text { from manufacturer to retailer }\end{array}$ & 2000.0 & 2100.0 & 2500.0 & 1900.0 & 2600.0 & 2300.0 & 2200.0 & 2300.0 & 2500.0 & 2500.0 \\
\hline $\begin{array}{l}\text { Products shipped } \\
\text { from manufacturer to distributor }\end{array}$ & 500.0 & 300.0 & 450.0 & 200.0 & 300.0 & 250.0 & 350.0 & 450.0 & 300.0 & 400.0 \\
\hline
\end{tabular}

Table 3 Efficiency scores

\begin{tabular}{|c|c|c|c|c|c|c|c|c|c|c|}
\hline & \multicolumn{5}{|c|}{ Member Efficiency } & \multicolumn{5}{c|}{ Supply Chain Efficiency } \\
\hline \multirow{2}{*}{ SC } & Supplier & Manufacturer & Distributor & Retailer & Average & Supply Chain & Supplier & Manufacturer & Distributor & Retailer \\
\cline { 2 - 12 } & $\theta_{S}^{*}$ & $\theta_{M}^{*}$ & $\theta_{D}^{*}$ & $\theta_{R}^{*}$ & & $\Omega^{*}$ & $\Omega_{S}^{*}$ & $\Omega_{M}^{*}$ & $\Omega_{D}^{*}$ & $\Omega_{R}^{*}$ \\
\hline 1 & 0.865 & 1 & 1 & 1 & 0.966 & 0.933 & 0.918 & 0.97 & 0.844 & 1 \\
\hline 2 & 0.881 & 1 & 0.88 & 0.673 & 0.859 & 0.669 & 0.6 & 0.625 & 0.465 & 0.714 \\
\hline 3 & 0.964 & 1 & 1 & 0.81 & 0.944 & 0.791 & 0.72 & 0.747 & 0.747 & 0.948 \\
\hline 4 & 0.87 & 0.856 & 1 & 0.754 & 0.87 & 0.576 & 0.518 & 0.46 & 0.658 & 0.667 \\
\hline 5 & 0.895 & 1 & 1 & 0.82 & 0.929 & 0.795 & 0.688 & 0.768 & 0.768 & 0.954 \\
\hline 6 & 0.937 & 0.999 & 1 & 0.673 & 0.902 & 0.613 & 0.529 & 0.579 & 0.625 & 0.717 \\
\hline 7 & 1 & 1 & 1 & 1 & 1 & 1 & 1 & 1 & 1 & 1 \\
\hline 8 & 1 & 1 & 0.811 & 1 & 0.953 & 0.943 & 1 & 1 & 0.77 & 1 \\
\hline 9 & 0.994 & 0.904 & 1 & 0.856 & 0.938 & 0.783 & 0.696 & 0.694 & 0.874 & 0.868 \\
\hline 10 & 1 & 0.986 & 1 & 1 & 0.997 & 0.992 & 1 & 0.968 & 1 & 1 \\
\hline
\end{tabular}

ステムはさらに入力を削減できることを意味している.

\section{3 効率的なサプライチエインになるための目 標值とベンチマーク}

モデル 2 では非効率的なサプライチエインが最良のパ フォーマンスを実現するための各入出力の最適值が得ら れるが, Table 4 に九つの非効率的なサプライチエインに 対してそれらが効率的となるための各入出力項目の最適 值を示している．たとえば SC 1 では $\Omega_{R}^{*}=1$ より小売業 者は効率的なので小売業者に関する入出力を調整する必 要はないが, 最良のパフォーマンスにするためには, サ プライヤ，生産者, 流通業者はそれぞれ $\Omega_{S}^{*}, \Omega_{M}^{*}, \Omega_{R}^{*}$ に基づいて直接入力を削減する必要がある。サプライヤ と生産者はサプライヤの収益を $6[\%]$ 増やすために原材 料の価格について調整しなければならない，流通業者の 在庫率を現在の $70[\%]$ から $90.95[\%]$ まで増加させ，生 産者から流通業者へ送られる製品を 39 [\%]減少させなけ ればならない，流通業者は生産者が納入する製品数を減
らしても在庫率 90.95 [\%] を保つようにしなければなら ない.

最適值 $\lambda_{j}^{*}, \beta_{j}^{*}, \delta_{j}^{*}, \gamma_{j}^{*}$ はどのサプライチエインのメ ンバーがベンチマークとなるかを表している. Table 5 に0でない $\lambda_{j}^{*}, \beta_{j}^{*}, \delta_{j}^{*}, \gamma_{j}^{*}$ の值を示している. たとえ ば SC 1 のベンチマークには， $\lambda_{7}^{*}=0.884$ より SC 7 の サプライヤ, $\beta_{2}^{*}=1.011$ より $\mathrm{SC} 2$ の生産者, $\delta_{3}^{*}=0.08$ と $\delta_{9}^{*}=0.893$ より $\mathrm{SC} 3$ と SC 9 の流通業者, $\gamma_{1}^{*}=1$ よ り SC 1 の小売業者自身がなっており，これらは効率的 であることがわかる。

$\theta_{\Delta}^{*}=1$ のときモデル 1 では $\phi_{j_{o}}^{*}=1$ となるものが必ず 存在するが，モデル 2 で対応する $\lambda_{j_{o}}^{*}, \beta_{j_{o}}^{*}, \delta_{j_{o}}^{*}, \gamma_{j_{o}}^{*}$ が 1 となることを示すものではない. たとえば SC 5 の生 産者は効率的であるが, モデル 2 では $\beta_{5}^{*}=0.768 \neq 1$ と なっている。 
Table 4 Optimal values for an efficient supply chain performance

\begin{tabular}{|c|c|c|c|c|c|c|c|c|c|}
\hline $\mathrm{SC}$ & 1 & 2 & 3 & 4 & 5 & 6 & 8 & 9 & 10 \\
\hline Labor & 137.7 & 84 & 93.6 & 85.5 & 116.9 & 76.7 & 175 & 111.3 & 125 \\
\hline Operating cost & 119.4 & 90 & 118.8 & 88.1 & 137.6 & 97.9 & 190 & 128.7 & 190 \\
\hline Revenure & 21.2 & 14.3 & 17.2 & 14.3 & 20.7 & 14.1 & 30 & 19.6 & 25 \\
\hline Manufacturing cost & 121.3 & 74.9 & 82.2 & 69 & 112.2 & 66.6 & 100 & 93.7 & 116.2 \\
\hline Manufacturing lead time & 2.9 & 1.2 & 2.2 & 1.8 & 1.5 & 1.7 & 2 & 2.8 & 2.9 \\
\hline Fill rate & $90.95[\%]$ & $54.22[\%]$ & $58.27[\%]$ & $49.08[\%]$ & $56.09[\%]$ & $48.54[\%]$ & $87[\%]$ & $66.47[\%]$ & $90[\%]$ \\
\hline Distributor inventory cost & 75.9 & 46.5 & 59.8 & 46.1 & 65.3 & 48.1 & 69.3 & 68.2 & 68 \\
\hline Distribution cost & 253 & 139.5 & 149.4 & 263.2 & 153.7 & 125 & 231 & 174.8 & 100 \\
\hline On-time delivery & $96[\%]$ & $58.46[\%]$ & $72.46[\%]$ & $56.82[\%]$ & $76.07[\%]$ & $58.74[\%]$ & $88[\%]$ & $82.66[\%]$ & $83[\%]$ \\
\hline Average number of backorder & 10 & 7.9 & 12.3 & 8.3 & 13.4 & 9.7 & 15.5 & 11.7 & 13 \\
\hline Retailer profit & 31000 & 22000 & 30000 & 23000 & 32000 & 24000 & 37000 & 32500 & 35500 \\
\hline $\begin{array}{l}\text { Products shipped } \\
\text { from distributor to retailer }\end{array}$ & 1800.0 & 1470.0 & 1634.0 & 1417.0 & 1741.0 & 1458.0 & 2000.0 & 2045.0 & 2300.0 \\
\hline $\begin{array}{l}\text { Products shipped } \\
\text { from manufacturer to retailer }\end{array}$ & 2000.0 & 1383.0 & 1868.0 & 1547.0 & 1998.0 & 1496.0 & 2300.0 & 2130.0 & 2500.0 \\
\hline $\begin{array}{l}\text { Products shipped } \\
\text { from manufacturer to distributor }\end{array}$ & 303.0 & 197.0 & 336.0 & 229.0 & 231.0 & 265.0 & 250.0 & 383.0 & 421.0 \\
\hline
\end{tabular}

Table 5 Benchmarks

\begin{tabular}{|c|c|c|c|c|}
\hline $\mathrm{SC}$ & Supplier & Manufacturer & Distributor & Retailer \\
\hline 1 & $\lambda_{7}^{*}=0.884$ & $\beta_{2}^{*}=1.011$ & $\begin{array}{l}\delta_{3}^{*}=0.080 \\
\delta_{9}^{*}=0.893\end{array}$ & $\gamma_{1}^{*}=1$ \\
\hline 2 & $\begin{array}{l}\lambda_{7}^{*}=0.036 \\
\lambda_{8}^{*}=0.448\end{array}$ & $\begin{array}{l}\beta_{2}^{*}=0.335 \\
\beta_{5}^{*}=0.106 \\
\beta_{7}^{*}=0.184\end{array}$ & $\begin{array}{l}\delta_{3}^{*}=0.124 \\
\delta_{9}^{*}=0.469\end{array}$ & $\gamma_{7}^{*}=0.629$ \\
\hline 3 & $\begin{array}{c}\lambda_{7}^{*}=0.039 \\
\lambda_{10}^{*}=0.317\end{array}$ & $\beta_{3}^{*}=0.747$ & $\delta_{3}^{*}=0.747$ & $\begin{array}{l}\gamma_{7}^{*}=0.114 \\
\gamma_{8}^{*}=0.703\end{array}$ \\
\hline 4 & $\begin{array}{l}\lambda_{7}^{*}=0.142 \\
\lambda_{8}^{*}=0.363\end{array}$ & $\begin{array}{l}\beta_{2}^{*}=0.033 \\
\beta_{3}^{*}=0.591\end{array}$ & $\begin{aligned} \delta_{3}^{*} & =0.361 \\
\delta_{9}^{*} & =0.220\end{aligned}$ & $\begin{array}{l}\gamma_{7}^{*}=0.273 \\
\gamma_{10}^{*}=0.379\end{array}$ \\
\hline 5 & $\begin{array}{c}\lambda_{8}^{*}=0.529 \\
\lambda_{10}^{*}=0.196\end{array}$ & $\beta_{5}^{*}=0.768$ & $\delta_{3}^{*}=0.768$ & $\begin{array}{l}\gamma_{8}^{*}=0.837 \\
\gamma_{10}^{*}=0.029\end{array}$ \\
\hline 6 & $\begin{array}{c}\lambda_{8}^{*}=0.246 \\
\lambda_{10}^{*}=0.269\end{array}$ & $\begin{array}{l}\beta_{3}^{*}=0.518 \\
\beta_{7}^{*}=0.091\end{array}$ & $\begin{array}{l}\delta_{3}^{*}=0.519 \\
\delta_{9}^{*}=0.084\end{array}$ & $\begin{array}{l}\gamma_{7}^{*}=0.171 \\
\gamma_{8}^{*}=0.487\end{array}$ \\
\hline 8 & $\lambda_{8}^{*}=1$ & $\beta_{8}^{*}=1$ & $\begin{array}{l}\delta_{3}^{*}=0.242 \\
\delta_{9}^{*}=0.672\end{array}$ & $\gamma_{8}^{*}=1$ \\
\hline 9 & $\begin{array}{c}\lambda_{8}^{*}=0.533 \\
\lambda_{10}^{*}=0.145\end{array}$ & $\beta_{3}^{*}=0.852$ & $\delta_{3}^{*}=0.852$ & $\begin{array}{l}\gamma_{7}^{*}=0.598 \\
\gamma_{10}^{*}=0.326\end{array}$ \\
\hline 10 & $\lambda_{10}^{*}=1$ & $\begin{array}{l}\beta_{2}^{*}=0.076 \\
\beta_{3}^{*}=0.498 \\
\beta_{7}^{*}=0.498\end{array}$ & $\delta_{10}^{*}=1$ & $\gamma_{10}^{*}=1$ \\
\hline
\end{tabular}

\section{5. 結論と今後の課題}

サプライチエインのパフォーマンスを記述するには複 数の評価尺度が必要であり, それらを統合して有効な評 価システムを構築しなければならない. 本論文ではDEA 効率性の概念を用いて, サプライチエインの効率性とと もにメンバーの効率性も測定するためのアプローチを 提供している. そして, サプライチエインの効率性を定 義するためのモデルを示し，メンバーが集団としてサプ ライチエイン全体のパフォーマンスを向上させるための
指針を与えている。提案モデルでは，どのようなサプラ イチエインに対しても, 最良のパフォーマンスを達成さ せるための目標とともに，ベンチマークとなるサプライ チエインを示すことができる，モデルでは効率的フロン ティア上の一つの目標を示すだけではあるが, 多目的意 思決定で用いられる対話型手法を使えば，他の目標を見 つけることもできる。

提案した方法は実際に得られたデータに基づいて効率 的なサプライチエインのパフォーマンスのフロンティア を推定するものである。メンバー間に存在する競合関係 のある実際のデー夕を使って解析するため, それらを反 映した最適值を示している. 個々のメンバーで取り決め た值では必ずしもサプライチエイン全体で効率的とはな らないが, 提案手法ではサプライチエイン全体が効率的 となるための最適値が示されている。サプライチエイン の最適構成を考える際, ゲーム理論とモデル 2 を組み合 わせることは今後の課題として興味深いものである.

ここでは確定的な線形計画問題に基づいた解析が行わ れている。製品や原材料の市場価格は変動しているが, 利益や収入といった価格データの代わりに製品数などの 数量デー夕を用いることで, その不確実性を回避してい る.しかし, 実際のサプライチエインは確率的に変動す る需要や供給のもとで運用されているため, 不確実性を 取り扱うにはモデルに確率的な要素を取り入れる必要が あり, 確率的 DEA モデル [7]の適用も今後の課題となる.

\section{謝辞}

この研究は日本学術振興会外国人招へい研究者（短期） 事業における共同研究によるものであり，ここに謝意を 表する。 


\section{参 考文 献}

[1] T. Altiok and R. Ranjan: Multi-stage, pull-type production/inventory systems; IIE Transactions, Vol. 27, pp. 190-200 (1995)

[2] W. W. Cooper, L. M. Seiford and K. Tone: Data Envelopment Analysis, Kluwer Academic Publishers (2000)

[3] K. L. Cheung and W. H. Hansman: An exact performance evaluation for the supplier in a two-echelon inventory system; Operations Research, Vol. 48, pp. 646-653 (2000)

[4] M. A. Cohen and H. L. Lee: Strategic analysis of integrated production-distribution systems: models and methods; Operations Research, Vol. 36, pp. 216228 (1988)

[5] L. B. Forker, D. Mendez and J. Hershauer: Total quality management in the supply chain: what is its impact on performance?; International Journal of Production Research, Vol. 35, pp. 1681-1702 (1997)

[6] H. L. Lee and C. Billington: Material management in decentralized supply chains; Operations Research, Vol. 41, pp. 835-847 (1993)

[7] H. Morita and L. M. Seiford: Characteristics on stochastic DEA efficiency - reliability and probability being efficient -; Journal of Operations Research Society of Japan, Vol. 42, No. 4, pp. 389-404 (1999)

[8] M. Parlar and Z. K. Weng: Designing a firm's coordinated manufacturing and supply decisions with short product life cycles; Management Science, Vol. 43, pp. 1329-1344 (1997)

[9] D. F. Ross: Competing Through Supply Chain Management, Kluwer Academic Publishers (1998)

[10] L. M. Seiford and J. Zhu: Profitability and mar- ketability of the top 55 US commercial banks; Management Science, Vol. 45, No. 9, 1270-1288 (1999)

[11] D. J. Thomas and P. M. Griffin: Coordinated supply chain management; European Journal of Operational Research, Vol. 94, pp. 1-15 (1996)

[12] 刀根：経営効率性の測定と改善, 日科技連 (1993) 